\title{
Identification of fungi species in the onychomycosis of institutionalized elderly
}

\author{
Identificação de espécies fúngicas nas onicomicoses do idoso institucionalizado \\ Cidia Vasconcellos ${ }^{1}$ \\ Carolina Queiroz Moreira Pereira ${ }^{2}$ \\ Marta Cristina Souza \\ Andrea Pelegrini ${ }^{4}$ \\ Roseli Santos Freitas ${ }^{5}$ \\ Juliana Possato Takahashi ${ }^{6}$
}

DOI: http://dx.doi.org/10.1590/abd1806-4841.20131884

\begin{abstract}
BACKGROUND: Superficial fungal infections are caused by dermatophytes, yeasts or filamentous fungi. They are correlated to the etiologic agent, the level of integrity of the host immune response, the site of the lesion and also the injured tissue. OвJеctive: The purpose of this study is to isolate and to identify onychomycosis agents in institutionalized elderly (60 years old +). METHODS: The identification of the fungi relied upon the combined results of mycological examination, culture isolation and micro cultures observation under light microscopy from nail and interdigital scales, which were collected from 35 elderly with a clinical suspicion of onychomycosis and a control group (9 elderly with healthy interdigital space and nails). Both groups were institutionalized in two nursing homes in Sao Bernardo do Campo, SP, Brazil. ResulTs: The nail scrapings showed $51.40 \%$ positivity. Of these, dermatophytes were found in $44.40 \%$ isolates, $27.78 \%$ identified as Trichophyton rubrum and $5.56 \%$ each as Trichophyton tonsurans, Trichophyton mentagrophytes and Microsporum gypseum. The second more conspicuous group showed $38.89 \%$ yeasts: $16.67 \%$ Candida guilliermondii, $11.11 \%$ Candida parapsilosis, 5.56\% Candida glabrata, and 5.56\% Trichosporon asahii. A third group displayed 16.70\% filamentous fungi, like Fusarium sp, Aspergillus sp and Neoscytalidium sp (5.56\% each). The interdigital scrapings presented a positivity rate of $14.29 \%$. The agents were coincident with the fungi that caused the onychomycosis. In the control group, Candida guilliermondii was found at interdigital space in one person. CONCLUSION: Employing a combination of those identification methods, we found no difference between the etiology of the institutionalized elderly onychomycosis from that reported in the literature for the general population.
\end{abstract}

Keywords: Arthrodermataceae; Fungi; Health of institutionalized elderly; Onychomycosis

Resumo: FUNDAMENTOS: As infecções fúngicas superficiais se correlacionam com o agente etiológico, a resposta imune do hospedeiro, o local da lesão e o tecido lesado, sendo causadas por dermatófitos, leveduras ou fungos filamentosos. OBjetivo: O objetivo é isolar e identificar os agentes das onicomicoses em idosos institucionalizados. MÉTODO: A identificação dos fungos baseou-se nos resultados combinados do exame micológico, isolamento em cultura e da observação de microculturas sob microscopia de luz, do material subungueal e escamas interdigitais, coletado de 35 idosos com suspeita clínica de onicomicose e de um grupo controle (9 idosos com espaço interdigital e unhas saudáveis). Ambos os grupos eram institucionalizados em duas casas de assistência em São Bernardo do Campo, SP, Brasil. Resultados: As unhas raspadas apresentaram 51,40\% de positividade. Os dermatófitos foram encontrados em 44,40\% de isolados, sendo 27,78\% identificados como Trichophyton rubrum e 5,56\%, cada, como Trichophyton tonsurans, Trichophyton mentagrophytes e Microsporum gypseum. O segundo grupo mais frequente (38,89\%) foi o de leveduras, identificadas como 16,67\% Candida guilliermondii, $11,11 \%$ Candida parapsilosis, 5,56\% Candida glabrata e 5,56\% Trichosporon asahii. Um terceiro grupo exibia 16,70\% fungos filamentosos, como Fusarium sp, Aspergillus sp e Neoscytalidium (5,56\% de cada). Os raspados interdigitais exibiram positividade de $14,29 \%$. Os agentes foram coincidentes com os fungos que causaram a onicomicose. No grupo controle, a Candida guilliermondii foi identificada no espaço interdigital em apenas uma pessoa. CONCLUSÃO: Empregando-se a combinação destes métodos de identificação, não houve diferença entre a etiologia da onicomicose dos idosos institucionalizados daquela relatada na literatura para a população em geral.

Palavras-chave: Arthrodermataceae; Fungos; Onicomicose; Saúde do idoso institucionalizado

Received on 22.05 .2012

Approved by the Advisory Board and accepted for publication on 06.08.2012.

* Work performed at the Medical Mycology Laboratory, Dermatology Department, at the University of São Paulo Medical School (FMUSP), the Institute of Medical Assistance to the State Public Server (IAMSPE) and the University of the City of São Paulo, Brazil (UNICID) - Tatuapé (SP), Brazil.

Conflict of interest: None

Financial funding: None

PhD and Professor at the post-graduate program of the University of São Paulo Medical School (FMUSP), the Institute of Medical Assistance to the State Public Server (IAMSPE) and the University of the City of São Paulo, Brazil (UNICID).

MSc at the post-graduate program in Health Sciences of the Department of Dermatology, at the University of São Paulo Medical School (FMUSP) - São Paulo (SP), Brazil. $\mathrm{PhD}$ at the post-graduate program in Microbiology and Immunology, at the Federal University of Sao Paulo (UNIFESP). Fleury Medical Diagnoses - São Paulo (SP), Brazil BSc, MSc, Department of Communicable Diseases - at the Federal University of Sao Paulo Medical School (UNIFESP). Fleury Medical Diagnoses - São Paulo (SP), Brazil. Biologist - BSc, MSc in Physiology - Technician of the Medical Mycology Laboratory of Tropical Medicine Institute at the University of Sao Paulo - Sao Paulo (SP), Brazil. BSc, MSc, Applied Microbiology - São Paulo State University. Fleury Medical Diagnoses - São Paulo (SP), Brazil. 


\section{INTRODUCTION}

Nail infections are usually fungal infections affecting the nails, accounting for $30 \%$ of the superficial skin infections and 50\% of all nail disorders. Its frequency is estimated at more than $10 \%$ in the general population and $40 \%$ in the elderly subjects, probably due to a weakened immune system, inactivity and inability to maintain good foot care, a reduced rate of growth of the nail plate throughout life and the increased possibility of trauma..$^{1-3}$ The infection is initiated at the free edge of the nail and can reach the subungueal area. The nails become yellowish-white, porous and brittle. ${ }^{3}$

Population ageing is a broad phenomenon: the World Health Organization predicts that by 2025 there will be 1.2 billion people over 60 years, with groups of 80 or more years constituting the fastest growing age group. In Brazil, it is estimated that there will be about 34 million elderly in 2025, leading the country to the 6th position among the most aged of the world. ${ }^{4}$ It is estimated that about $10-15 \%$ of the human population might be infected by any fungi in the course of their life. $^{5}$

\section{METHODS}

From March 2009 to July 2010 mycological examination of subungueal and interdigital foot scales of 35 institutionalized patients ( 60 years old + ) in two public nursing homes in Sao Bernardo do Campo, SP, Brazil were performed. All patients or their guardians' agreement to participate in this study were documented by an Informed Consent Form. Nine subjects without nail lesions were selected as control and their scales were collected from the interdigital space.

The exclusion criteria were a newly manicured nail or any recent antifungal treatment. The samples were processed in the Mycology Laboratory in three methods: one part was clarified with $\mathrm{KOH}$ for visualization of fungal elements and the other two were harvested on both Sabouraud dextrose agar with chloramphenicol and Mycosel. The identification was performed though evaluation of macro and micro morphological features. Some doubtful cases where harvested also in the potato dextrose agar medium (dermatophytes or non-dermatophyte fungi) or cornmeal agar-Tween 80 (yeasts).

The research received the Protocol Approval $171 / 11$ by the Ethics Committee for Analysis of Research Projects of the Clinical Board of University of Sao Paulo Medical School.

\section{RESULTS}

The 35 patients with onychodystrophy had a mean age of 86 years (from $65 \mathrm{y} / \mathrm{o}$ to $98 \mathrm{y} / \mathrm{o}$ ), and the rate of infection was 11 females / 7 males, among the
18 confirmed onychomycosis, either as 18 positive results on direct examination or 15 positive cultures.

The 8 identified dermatophytes were: 5 Trichophyton rubrum and 1 of each of Trichophyton tonsurans, Microsporum gypseum, and Trichophyton mentagrophytes. The second most frequently isolated group comprised 7 yeasts: 3 Candida guilliermondii, 2 Candida parapsilosis, 1 Candida glabrata and 1 Trichosporon asahii. The last group was composed of 3 isolates of non-dermatophyte moulds, identified as: Fusarium sp Aspergillus sp and Neoscytalidium sp.

The interdigital scrapings were positive in 5 patients and coincided with the fungi that caused the onychomycosis (2 Trichophyton rubrum, 1 Trichophyton mentagrophytes, 1 Candida guilliermondii and 1 Fusarium sp). In the control group only 1 Candida guilliermondii was isolated.

\section{DISCUSSION}

Toenail infections are a major problem in dermatology clinics with high frequency and potential to influence the quality of life of patients. ${ }^{6}$ Nail infections are less common in fingernails than in toenails, and the frequency is influenced by age, lifestyle or presence of concomitant diseases. ${ }^{2}$

Senility is considered a risk factor for onychomycosis and there are some explanations for this: poor peripheral circulation, the higher frequency of diabetes mellitus in this age group, bigger chance of repeated nail trauma, longer exposure to the fungal pathogen, disabilities to cut toenails by physical limitations and the slower growth of the nails in the elderly. ${ }^{7}$

Onychomycosis can be aggravated by other medical conditions, especially in the elderly, such as bacterial infections, sometimes reaching lower-limb amputations in patients with diabetes mellitus. Furthermore, diabetic patients have a higher prevalence of onychomycosis than non-diabetics.

A study on the prevalence of dermatoses in elderly residents of nursing homes, stated that $10 \%$ suffered from onychomycosis. ${ }^{8}$ The lower extremity represented the second most common site of skin lesions in geriatric patients.

Among the 108 residents in the two studied facilities, about $80.00 \%$ had fungal infection, of which $32.41 \%$ fulfilled the inclusion criteria.

Some authors observed a preponderance of females over males in the frequency of onychomycosis, with values between 65.00 and $80.00 \%$. 3,9,10

In this study, onychomycosis occurred in $61.00 \%$ of institutionalized elderly females, agreeing with the findings in the literature for the general population.

Usually there is discrepancy between the myco- 
logical examination and the culture and, sometimes, one is positive and the other is negative, a fact that can be explained by the uneven distribution of fungi in the lesions, the difficulty of collecting adequate material, especially from the subungueal area; the ease with which crops contaminate, due to environmental fungi and bacterial micro biota, making it difficult to identify the true causative agent. There are also the inherent exam limitations, such as brisk keratinization of nail material hindering the microscopic observation and the viability of fungal microorganisms, which can result in false negative cultures due to previous treatment, even after one week of drug withdrawal, and the growth of fungal contaminants, preventing the growth of the true pathogen..$^{10,11}$

A study of 2,065 collected specimens found nail mycological examination positive in 1,707 people. Among these, the culture was positive for fungi in $1,069 .{ }^{12}$ More recently, another series obtained 1,282 mycological examination and positive cultures, out of a total of 2,273 samples from patients with nail dystrophy. ${ }^{13}$

The results of this research are in accordance with the above-mentioned studies, since, among those who had positive direct mycological examination, culture was also positive in $83.00 \%$.

The distribution of etiologic agents of onychomycosis is not uniform, depending on factors such as climate, geography, and migration flow. ${ }^{2}$

In this study, dermatophytes were responsible for most nail infections, representing $44.40 \%$ of the positive cultures, with $\mathrm{T}$. rubrum being the main agent $(27.78 \%)$, followed by T. mentagrophytes, T. tonsurans and M. gypseum. Among dermatophytes, T. rubrum and $\mathrm{T}$. mentagrophytes are the main fungi responsible for the high prevalence of dermatophytosis in the general population. ${ }^{13}$

This work achieved similar results: the most

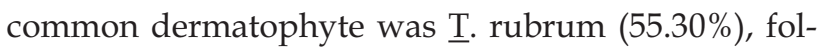
lowed by $\mathrm{T}$. mentagrophytes $(43.70 \%)$.

We observed that the infections caused by Candida sp species accounted for $38.80 \%$. There are several factors that may contribute to the predominance of this framework, such as hands and feet being subjected to constant moisture, infection during personal hygiene or the state of immunosuppression. ${ }^{14,15}$ Moreover, there is an increase in its prevalence as etiological agents of dermatophytosis. ${ }^{16}$
To impute an onychomycosis to a filamentous fungus, the collection of the sample must be repeated on different dates and it is usually associated with a history of immunosuppression..$^{13}$ According to this criterion, three people had onychomycosis caused by this type of fungi in this study and the concept of a poor immune response is important, since in this work all participants had more than 65 years of age.

In a study conducted in South Florida with 450 patients over 65 years of age, the agents isolated on the collected samples were: 85 (16.20\%), Aspergillus sp., followed by 71 (13.50\%) of Trichophyton rubrum, $58(11.00 \%)$ of Candida parapsilosis and $33(6.30 \%)$ Trichophyton mentagrophytes. ${ }^{17}$

Due to the fact that dermatomycoses do not have a compulsory notification, there is no real knowledge of the extent of this problem in the population, although one study demonstrated that the rate of these disorders have significantly increased, especially in elderly patients. ${ }^{18}$

It is estimated that onychomycosis is more common in elderly people as compared to other age groups. The exact incidence of onychomycosis is unknown, but the reported rate ranges from $2 \%$ to $13 \%$ in the general population. Thirty two percent of the population aged from 60 to 70 years is affected as well as more than $48 \%$ of those over the age of $70 .{ }^{17}$ This work, although small in its size, showed frequencies of onychomycosis and its causative agents in the elderly similar to those of the general population.

Onychomycosis can cause health risks, particularly in the elderly and their consequences along the time, mainly in institutionalized individuals, may be more expensive than treating individuals currently infected.

\section{CONCLUSION}

The identification method detected that the frequency of fungi causing onychomycosis in this study is consistent with the profile of recent reports in the literature for the general population.

From the etiological point of view, no difference was observed between the data of onychomycosis of institutionalized elderly people when compared to the occurrence of onychomycosis in the general population, as reported in the literature until now. $\square$ 


\section{REFERENCES}

1. Rodrigues-Soto ME, Fernandez-Andreu CM, Duque SM, Diaz RMR, Martinez-Machin G. Clinico-mycological study of onychomycosis in elderly patients. Rev Inst Med Trop São Paulo. 1993;35:213-7.

2. Shemer A, Trau H, Davidovici B, Amichai B, Grunwald MH. Onychomycosis: rationalization of topical treatment. Isr Med Assoc J. 2008;10:415-6.

3. Araujo AJG, Bastos OMP, Souza MAJ, Oliveira JC. Occurrence of onychomycosis among patients attended in dermatology offices in the city of Rio de Janeiro, Brazil. An Bras Dermatol. 2003;78:299-308.

4. Davim RBM, Torres GV, Dantas SMM, Lima VM. Study with elderly from asylums in Natal/RN: socioeconomic and health characteristics. Rev. Latino-Am Enfermagem. 2004; $12: 518-24$

5. Costa M, Passos XS, Souza LKK, Miranda ATB, Lemos, JA, Junior, JGO, Silva MRR Epidemiology and etiology of dermatophytosis in Goiânia, GO, Brazil. Rev Soc Bras Med Trop. 2002;35:19-22.

6. Purim KSM, Bordignon GPF, Queiroz-Telles F. Fungal infection of the feet in soccer players and non-athlete indviduals. Rev Iberoam Micol. 2005;22:34-8.

7. Cursi IB, Freitas LBCR, Neves MLP, Silva IC, Orofino-Cosra R. Onycomychosis due to Scytalidium spp.: a clinical and epidemiologic study at a University Hospital in Rio de Janeiro, Brazil. An Bras Dermatol. 2011;86:689-93.

8. Dinato SLM, Oliva R, Dinato MM, Macedo-Soares A, Bernardo WM. Prevalence of dermatoses in residents of institutions for the elderly. Rev Assoc Med Bras. 2008;54:543547.

9. Martins EA, Guerrer LV, Cunha KC, Soares MMCN, Almeida MTG. Onychomycosis: clinical, epidemiological and mycological study in the municipality of São José do Rio Preto. Rev Soc Bras Med Trop. 2007:40:596-8.

10. Martelozo IC, Guilhermetti E, Svidzinski TIE. Occurrence of the onychomycosis in Maringá, Paraná State, Brazil. Acta Sci. Health Sci. 2005;27:177-82.

11. Carvalho MTF. Pesquisa de fungos em unhas de pacientes HIV soropositivos [tese] São Paulo (SP): Universidade Federal de São Paulo; 1990.

12. Elewski BE. Onychomycosis: pathogenesis, diagnosis, and management.Clin Microbio Rev. 1998;11: 415-29.

13. Roth DE, editor. Dermatology Research focus on acne, melanoma and psoriasis. New York: Nova Science Pub Inc; 2010. Chapter 16, Onychomycosis caused by nonderma- tophytic filamentous fungi; p.293-305.

14. Luque AG, Ramos LL, Susana LA, Riccomi AE. Mycological study of 100 cases of ungual lesions of Rosario city (República Argentina). Rev Iberoam Micol. 1997;14:164 7.

15. Palacio A, Cuétar MS, Valle A, González A, Almondarain I, Castillo MJR, Vasallo AM, Miguens MP. Dermatophytes isolated in Hospital Universitario "12 de Octubre" (Madrid, Spain). Rev Iberoam Micol. 1999;16:101-6.

16. Pelegrini A, Takahashi JP, Pereira CQM, Pessoni RB, Souza MC. Incidence of dermatophytosis in a public hospital of São Bernardo do Campo, São Paulo State, Brazil. Rev Iberoam Micol. 2009;26:118-120.

17. Scherer WP, McCreary JP, Hayes WW. The diagnosis of onychomycosis in a geriatric population: a study of 450 cases in South Florida. J Am Podiatr Med Assoc. 2001;91:456-64

18. Xavier APM, Oliveira JC, Ribeiro VLS, Souza MAJ. Epidemiological aspects of patients with ungual and cutaneous lesions caused by Scytalidium spp. An Bras Dermatol. 2010;85:805-10.

\author{
MAILING ADDRESS: \\ Cidia Vasconcellos \\ Rua Campevas, 639 \\ 05016-010 - Sao Paulo - SP \\ E-mail: cidiav@ig.com.br
}

How to cite this article: Vasconcellos C, Pereira CQM, Souza MC, Pelegrini A, Freitas RS, Takahashi JP. Identification of fungi species in the onychomycosis of institutionalized elderly. An Bras Dermatol. 2013;88(3):377-80. 